\title{
Use of Silicon to Preserve Sucrose in Sugarcane Desiccated with Paraquat and Diquat
}

\author{
Alex G. Alexander and Rafael Montalvo-Zapata
}

\section{INTRODUCTION}

Recent work in Puerto Rico has shown a marked decline of sucrose in sugarcane sprayed with Paraquat ${ }^{2}$ and Diquat. ${ }^{3}$ This decline is specifically attributed to a disruption of photosynthesis and stimulation of metabolic enzymes $(7,8)^{4}$ From a practical standpoint this tends to negate the useful roles of such materials in cane desiccation and flower control.

In a larger sense the investigator is confronted with a very significant question: Is it possible to modify the behavior of an argicultural chemical so that its undesirable effects are suppressed while useful ones are retained? Having advanced creditable theories of biochemical action, the scientist can substantiate the theories by selectively modifying adverse chemical effects. In so doing he gives insight toward more productive chemical usage.

Summarized herein are greenhouse and laboratory experiments in which silicon ( $\mathrm{Si}$ ) was used to preserve sucrose in cane treated with Paraquat and Diquat. There were three objectives: 1 , To incorporate sufficient Si into living sugarcane tissues to retard metabolic enzymes, particularly amylase and invertase; 2, to retain photosynthetic activity in desiccant-treated leaves; and 3, to maintain a significantly higher level of sucrose as a consequence of lessened metabolism and continued photosynthesis.

\section{MATERIALS AND METHODS}

\section{GROWTH AND SAMPLING OF PLANT MATERIALS}

Three experiments were conducted in the greenhouse with plants of the variety P.R. 980. All plants were grown by the sand culture technique previously described (1). Essentially an extension of the laboratory, the greenhouse is not used here as a field substitute. Rather, it produces in $\mathbf{1 0}$ to 12 weeks a uniform stand of living material. Within this stand individual plants can be treated, harvested, and analyzed with precision unattainable under field conditions.

\footnotetext{
1 Plant Physiologist and Assistant Chemist, Agricultural Experiment Station, Mayagüez Campus, University of Puerto Rico, Río Piedras, P.R.

2 1,1' dimethyl-4,4-bipyridilium-bis-dimethyl sulfate, commercially known as "Gramoxone".

6,7-dihydrodipyrido $\left(1,2-8: 2^{\prime}, 1^{\prime}\right.$-c)-pyrazidilium salt, commercially known as "Reglone".

- Italic numbers in parentheses refer to Literature Cited, pp. 262-3.
} 
For each experiment plants were sprayed once with aqueous desiccant solution containing Tween 20 as wetting agent at the rate of 1 milliliter per liter of solution. Control plants received Tween 20 in distilled water. Solutions were applied with a Hudson hand sprayer until all above-sand tissues were wetted. Tissue samples were harvested a few moments before desiccant treatment ( 0 days) and again 5 days later. Leaf and immature storage tissues were frozen, lyophilized, ground to pass a 60 -mesh screen, and stored at $-10^{\circ} \mathrm{C}$. as previously described (1). Leaf sheaths were retained for percent-moisture determinations, and millable stalks were ground with a small laboratory mill for Brix and polarization analyses.

For experiment 1, 16-week old plants were sprayed with 6 levels of Paraquat. These included 0, 0.0002, 0.0006, 0.0018, 0.0054, and 0.0162 percent solutions. Half of the plants were given $\mathrm{Si}$ as a foliar spray at 8 days, 4 days, and 1 day prior to Paraquat treatment. Sodium meta-silicate $\left(\mathrm{Na}_{2} \mathrm{SiO}_{3} \cdot 9 \mathrm{H}_{2} \mathrm{O}\right)$ was employed as $\mathrm{Si}$ source at the rate of 500 p.p.m. of elemental Si. The remaining plants were pretreated with water and wetting agent only. Experiment 2 was identical to experiment 1 with the exception that younger plants were used (12 weeks) and Diquat was substituted for Paraquat. For experiment 3, Paraquat was applied at rates of $\mathbf{0}$ and 0.001 percent, and a single Si pretreatment was applied 1 day before the desiccant. Randomized block designs were used for experiments 1 and 2, with two and three replicates respectively. A $2 \times 2$ factorial design with three replicates was employed for experiment 3.

\section{LABORATORY ANALYSES}

Clarified water extracts of the tissue powder were analyzed for total ketose by the resorcinol method of Roe (19), and for sucrose by the modification of Cardini et al. (11). Fructose was estimated by subtracting sucrose values from those of total ketose. Reducing sugars were estimated by the dinitrosalicylic acid method of Sumner (14).

Protein was precipitated from water extracts with solid ammonium sulfate as previously described (1). The 0-80 percent fraction was used for enzyme analysis following 2 hours dialysis against 2 changes of distilled water. Acid phosphatase and ATP-ase was measured in accordance with methods described previously (2), as was invertase (3), amylase (4), peroxidase (5), and polyphenol oxidase (6). The method of Sutherland et al. (15) was used to measure both the water-soluble protein of tissue samples and the protein content of enzyme preparations. Enzyme action was computed as specific activity (activity units per mg. of protein).

Samples of clarified tissue extracts were chromatographed on Whatman no. 1 filter paper using the solvent mixture butanol-pyridine-water $(6: 4: 3$, $\mathrm{v} / \mathrm{v})$ in one dimension. The extracts were concentrated by freeze-drying 
prior to application. Reference and unknown sugar spots were developed by the silver nitrate method of Dube and Nordin (12).

Biochemicals were obtained from the Nutritional Biochemicals Corporation, Cleveland, Ohio. Paraquat and Diquat were supplied by local representatives of the Chevron Chemical Company, Ortho Division.

\section{RESULTS AND DISCUSSION}

\section{EXPERIMENT 1: INCREASING PARAQUAT $X$ SI}

\section{Visual Responses to Paraquat and Si}

Plants were treated at 4:30 p.m., July 12, under cloudy and cool conditions. No injury symptoms appeared that day although nearly 3 hours of full daylight remained. The following morning was clear and warm. Symptoms began to appear among the higher desiccant treatments shortly before

TABLE 1.-Shealh moisture content of sugarcane desiccated with Paraquat and pretreated with variable $\mathrm{Si}^{1}$

\begin{tabular}{c|c|c|c|c|c|c|c}
\hline \multirow{3}{*}{ Si (p.p.m.) } & \multirow{5}{*|}{} & \multicolumn{5}{|c|}{ Paraquat (percent solution X 104) } & \multirow{2}{*}{ Paraquat mean } \\
\cline { 2 - 6 } & & 2 & 6 & 18 & 54 & 162 & \\
\hline 0 & 81.3 & 85.4 & 81.1 & 82.2 & 75.9 & 73.6 & 79.6 \\
500 & 79.4 & 79.2 & 80.7 & 80.3 & 81.3 & 75.8 & 79.5 \\
\hline
\end{tabular}

1 Each figure represents the computed mean of 2 replicates.

noon. These were typically expressed as general wilting, turning of color from green to olive green, and then to grey and yellow-brown, accompanied by drying of leaf blades and sheaths. Paraquat injury symptoms are thoroughly described elsewhere $(7,8)$.

At 24 hours after treatment the two highest Paraquat levels were causing severe desiccation of non-Si treated plants. However, the Si-treated plants were clearly resisting foliar injury. In general the plants given Si remained green for two higher Paraquat increments than non-Si plants. In other words, typical injury symptoms produced by 0.0018 percent Paraquat, without $\mathrm{Si}$, did not find counterparts in Si-treated plants until the $\mathbf{0 . 0 1 6 2}$ percent level was reached. Thus in outward appearance the Si pretreatment was about comparable to a 1 to 9 dilution of the desiccant. This visual relationship was retained for the duration of the study.

\section{Moisture and Sugar Responses to Paraquat and Si}

Sheath moisture values ultimately dropped in response to Paraquat regardless of Si treatment (table 1). However, this moisture decline, which 
Table 2.-Leaf sucrose content of sugarcane desiccated with Paraquat and pretreated with variable Si1

\begin{tabular}{|c|c|c|c|c|c|c|c|}
\hline \multirow{2}{*}{$\underset{\text { (p.p.m.) }}{\mathbf{S i}}$} & \multirow{2}{*}{0} & \multicolumn{5}{|c|}{ Parequat (percent solution $\left.\times 10^{4}\right)-$} & \multirow{2}{*}{$\begin{array}{c}\text { Paraquat } \\
\text { mean }\end{array}$} \\
\hline & & 2 & 6 & 18 & 54 & 162 & \\
\hline $\begin{array}{r}0 \\
500\end{array}$ & $\begin{array}{l}38.5 \\
30.1\end{array}$ & $\begin{array}{l}32.6 \\
28.4\end{array}$ & $\begin{array}{l}33.4 \\
28.3\end{array}$ & $\begin{array}{l}20.9 \\
28.2\end{array}$ & $\begin{array}{r}5.5 \\
26.9\end{array}$ & $\begin{array}{r}2.9 \\
14.2\end{array}$ & $\begin{array}{l}19.1 \\
25.2\end{array}$ \\
\hline
\end{tabular}

1 Each figure represents the computed mean of 2 replicates.

TABLD 3.-Sucrose content of immature storage tissue from sugarcane desiccated with Paraquat and pretreated with variable $S i^{2}$

\begin{tabular}{c|c|c|c|c|c|c|c}
\hline \multirow{2}{Si}{} & & \multicolumn{5}{|c|}{ Paraquat (percent solution $\times 104)-$} & $\begin{array}{c}\text { Paraquat } \\
\text { mean }\end{array}$ \\
\cline { 3 - 7 } & 0 & 2 & 6 & 18 & 54 & 162 & \\
\hline 0 & 79.2 & 82.8 & 98.4 & 82.2 & 38.4 & 33.9 & 51.1 \\
500 & 87.6 & 107 & 76.5 & 70.8 & 92.0 & 83.9 & 86.2 \\
\hline
\end{tabular}

1 Each figure represents the computed mean of 2 replicates.

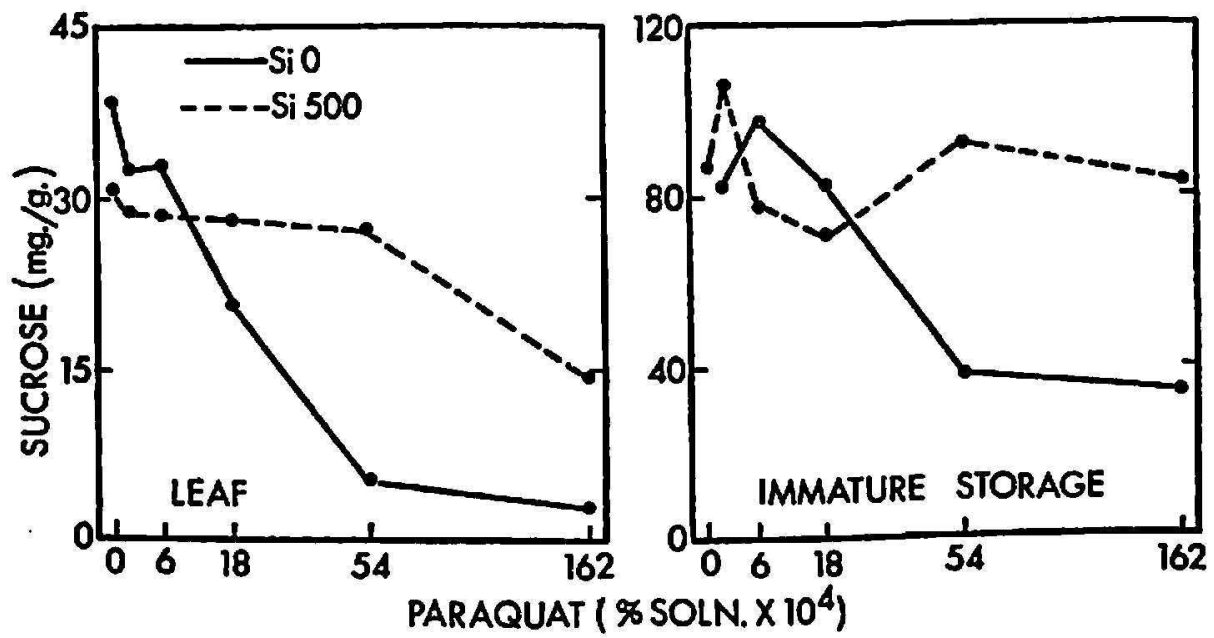

FiG. 1.-Sucrose decline in leaf and immature storage tissues of sugarcane treated with Paraquat, and sucrose preservation in plants pretreated with Si. (Point 0, 79.2 of curve Si 0 is missing. Refer to table 3.)

occurred in the range 0.0018 to 0.0054 percent without $\mathrm{Si}$, was moved forward to the range 0.0054 to 0.0162 by the Si treatment. The grand means for Paraquat at the two Si levels are identical. This was due to a stabilizing effect of Si on sheath moisture at the lower desiccant levels, the water content tending to fluctuate upward when no Si was given.

As expected, Paraquat caused major sucrose losses in leaf and immature storage tissues (tables 2 and 3). At the lower Paraquat levels Si managed 
to depress sucrose in leaves and to increase it in immature storage tissue; but, quite significantly, the higher desiccant levels failed to cause severe sucrose losses in Si-treated tissues (fig. 1). Again, the critical range of leaf sucrose destruction was moved forward about 9 -fold, corresponding to the visual Si preservation of green leaves described above. Sucrose in immature

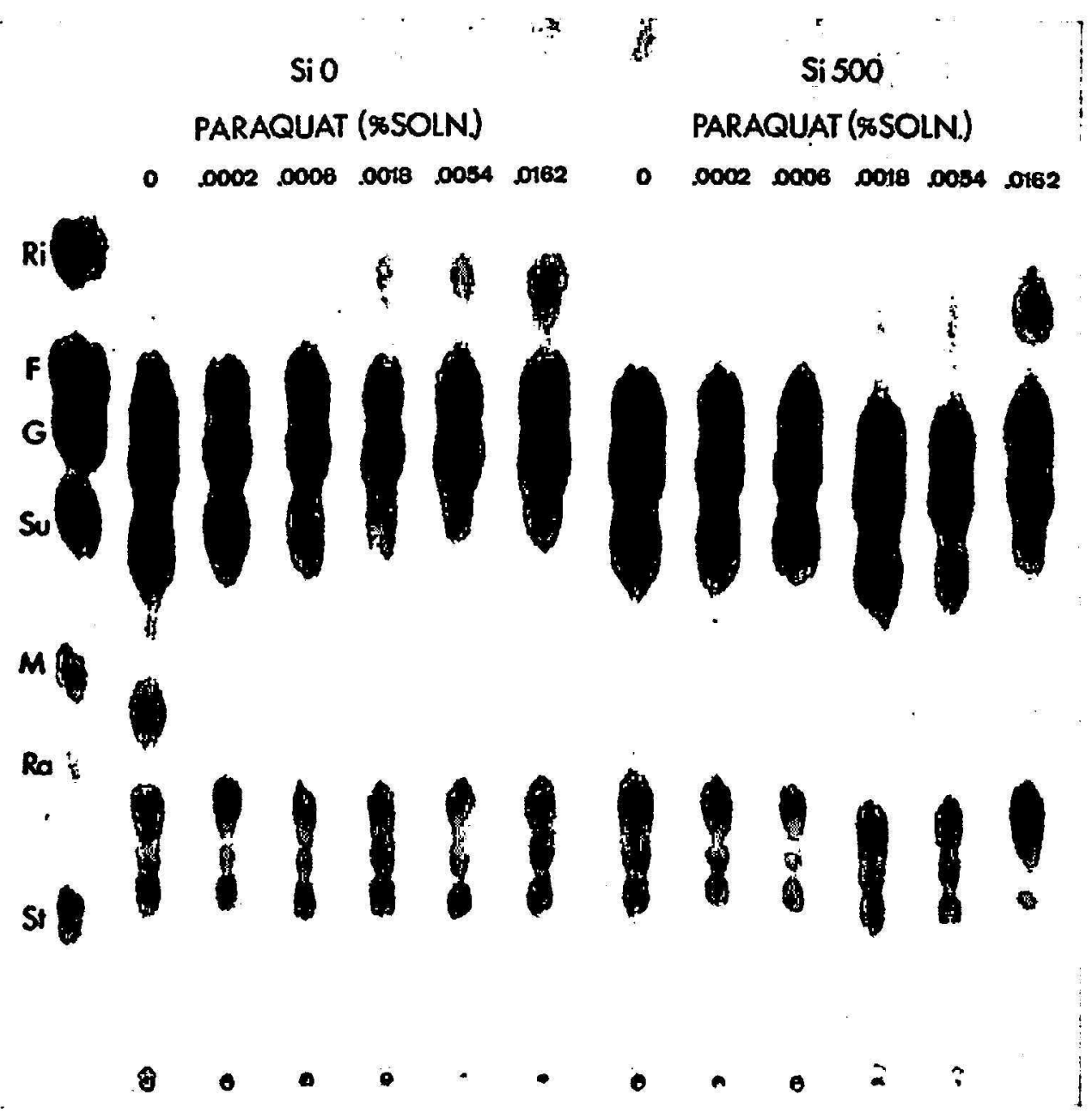

Fig. 2.-Paper chromatogram of leaf extracts from sugarcane treated with Paraquat, and pretreated with variable Si. Illustrated are the following: 1 , The appearance of ribose ( $\mathrm{Ri}$ ) with increasing Paraquat concentration; 2, delay of the ribose appearance in plants sprayed with 500 p.p.m. Si; 3 , loss of sucrose (Su) as Paraquat level was raised; and 4, retention of sucrose in plants pretreated with $\mathrm{Si}$. Reference sugars are identified as follows: $\mathrm{I} i=$ ribose; $\mathrm{F}=$ fructose; $\mathrm{G}=$ glucose; $\mathrm{Su}=$ sucrose; $\mathrm{M}=$ melezitose; $\mathrm{Ra}=$ raffinose and $\mathrm{St}=$ stachyose.

storage tissues was thoroughly protected from the depressing desiccant action, the latter being very evident in plants pretreated with water rather than Si solution.

From the results outlined above it is clear that Si pretreatments helped to preserve green foliar tissues and to retain higher sucrose levels in plants experiencing desiccative action. Paper chromatography of leaf extracts, illustrated by figure 2 , confirmed the Si-desiccant relationships. The upper- 
most spots, corresponding to reference "Ri", represent ribose and signify a disruption of photosynthetic pathways at the site of phosphoribose isomerase activity (7). Plants receiving no $\mathrm{Si}$ accumulated ribose between the 0.0018 and 0.0162 percent levels of Paraquat. In plants treated with Si there was a tendency for photosynthesis to continue up to the highest desiccant level, 0.0162 percent. As little as $1 / 9$ of that level was disrupting photosynthesis in the absence of Si. Figure 2 also illustrates the fading of sucrose spots as a function of increasing Paraquat where no Si was given. Sucrose spots are clearly retained regardless of Paraquat in Si-treated plants.

TABLE 4.-Specific activity values for leaf enzymes of sugarcane desiccaled with Paraqual and pretreated with variable Sil

\begin{tabular}{l|r|c|c|c|c|c|c|c}
\hline \multirow{2}{*}{ Enzyme } & $\begin{array}{c}\text { Si } \\
\text { (p.p.m.) }\end{array}$ & 0 & \multicolumn{5}{|c|}{ Paraquat (percent solution $\times 10^{4}$ ) } & Paraquat \\
\cline { 4 - 7 } & & & 2 & 6 & 18 & 54 & 162 & \\
\hline Phosphatase & 0 & 22.9 & 21.8 & 24.7 & 18.5 & 10.8 & 10.5 & 17.3 \\
& 500 & 21.5 & 21.3 & 22.3 & 21.8 & 19.6 & 15.5 & 20.1 \\
ATP-ase & 0 & 35.3 & 35.7 & 35.2 & 27.8 & 13.2 & 12.0 & 24.8 \\
& 500 & 33.7 & 29.2 & 28.2 & 28.8 & 26.9 & 17.5 & 26.1 \\
Amylase & 0 & 285 & 244 & 436 & 218 & 268 & 313 & 296 \\
& 500 & 211 & 236 & 179 & 162 & 250 & 281 & 222 \\
Peroxidase & 0 & 167 & 122 & 116 & 79 & 45 & 31 & 79 \\
& 500 & 95 & 83 & 104 & 117 & 86 & 68 & 92 \\
\hline
\end{tabular}

1 Each figure represents the computed mean of 2 replicates.

\section{Enzyme Responses to Paraquat and Si}

The selection of $\mathrm{Si}$ as a possible desiccant-modifying agent was based on two factors: 1, It is an excellent in vitro inhibitor of hydrolytic and oxidative enzymes $(9,10)$; and 2, previous work had revealed a stimulating effect of Paraquat on amylase (7). The choice of $\mathrm{Si}$ has proven to be a happy one. The peculiar treatments designed for these experiments made it possible to verify Si-enzyme relationships and to study them in several dimensions not afforded by the test tube.

Of the leaf enzymes assayed, all except amylase lost activity as the desiccant level was raised (table 4). In each instance Si acted to counter this loss. It thus appears that the enzyme-Si complex leading to inhibition in the test tube served to protect the enzymes from a more destructive agent, Paraquat, under in vivo conditions. 
As anticipated, amylase action tended to shift upward in response to Paraquat (table 4). Si succeeded in retarding amylase at each Paraquat level (fig. 3, A). The Si effect was not extensive and seems more like a modification of abnormal action rather than outright inhibition as observed in the test tube. An extremely important enzyme from immature storage tissue, invertase, was also stimulated by higher Paraquat concentrations, table 5 , and $\mathrm{Si}$ again served to check the increase rather than to totally inhibit activity (fig. $3, \mathrm{~B}$ ).

This "modification" of enzyme extremes is well illustrated by leaf peroxidase (table 4). Where Si was applied to control (0 Paraquat) plants an actual Si inhibition seemed to be in effect. However, Paraquat shifted the

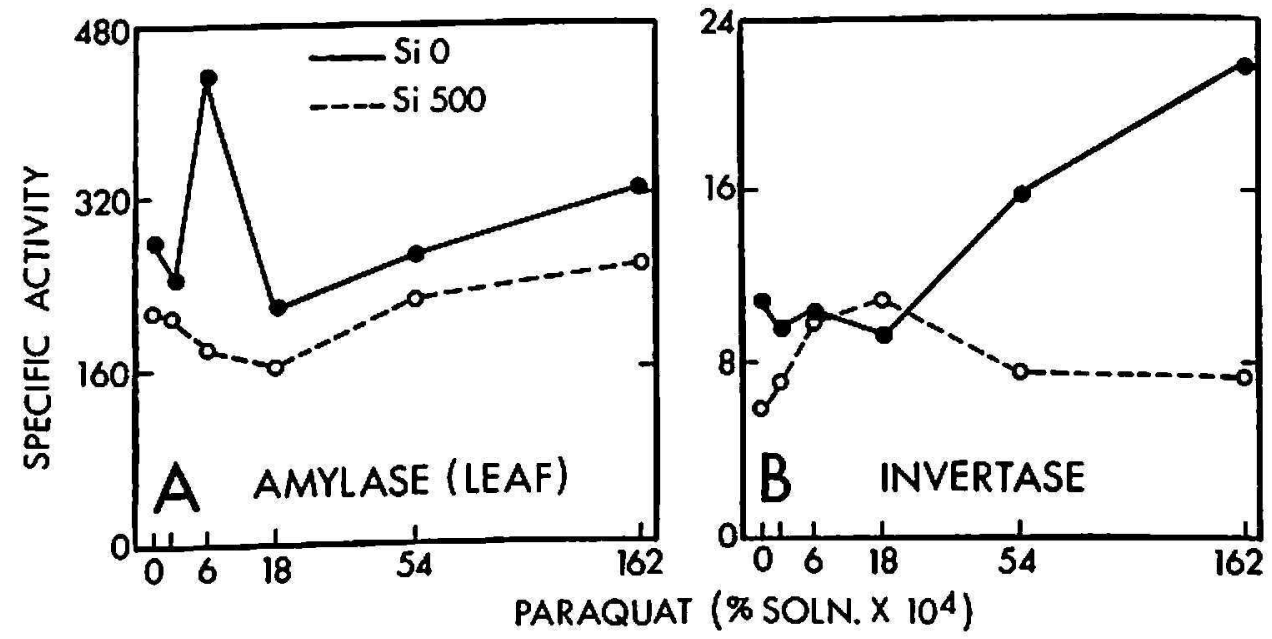

Fig. 3.-Leaf amylase and invertase increase in sugarcane treated with Paraquat, and suppression of the two enzymes in plants pretreated with Si. (On curve Si 500, point 0,211 should be lower than point 2,236 . Refer to table 4 .)

initially high peroxidase activity downward until it passed far below that of the Si-treated plants (fig. 4). In the latter plants peroxidase was able to perform at a more or less constant level in spite of Paraquat treatments.

Considering the vast difference between in vitro and in vivo conditions, it is remarkable that such definite Si-enzyme relationships could be recorded for the living plant. We are not clear at this time regarding the $\mathrm{Si}$ "protection" of photosynthetic activity; however, once the sucrose was formed its prospects for survival were certainly boosted by the Si modification of hydrolytic and oxidative enzymes noted above.

\section{EXPERIMENT 2: DIQUAT $\times$ SI}

Diquat, as a quaternary ammonium compound, is chemically related to Paraquat. Although its desiccative action on sugarcane appears identical to that of Paraquat $(7,8)$, it is a distinct entity in the family of agricultural 
TABLE 5.-Specific activity values for immature slorage tissue enzymes of sugarcane desiccaled with Paraqual and prelreated wilh variable Si1

\begin{tabular}{|c|c|c|c|c|c|c|c|c|}
\hline \multirow{2}{*}{ Enzyme } & \multirow{2}{*}{$\underset{\text { (p.p.m.) }}{\mathrm{Si}}$} & \multirow{2}{*}{0} & \multicolumn{5}{|c|}{ Paraquat (percent solution $\left.\times 10^{4}\right)-$} & \multirow{2}{*}{$\begin{array}{c}\text { Paraquat } \\
\text { mean }\end{array}$} \\
\hline & & & 2 & 6 & 18 & 54 & 162 & \\
\hline \multirow[t]{2}{*}{ Phosphatase } & 0 & 10.2 & 10.7 & 12.8 & 13.6 & 12.1 & 17.0 & 13.2 \\
\hline & 500 & 8.2 & 10.0 & 11.5 & 12.0 & 11.7 & 11.3 & 11.3 \\
\hline \multirow[t]{2}{*}{ ATP-ase } & 0 & 10.5 & 10.3 & 14.6 & 16.2 & 13.4 & 15.5 & 14.0 \\
\hline & 500 & 8.1 & 9.6 & 10.3 & 12.4 & 10.7 & 9.9 & 10.6 \\
\hline \multirow[t]{2}{*}{ Amylase } & $\mathbf{0}$ & 105 & 84 & 97 & 108 & 117 & 152 & 111 \\
\hline & 500 & 104 & 144 & 160 & 168 & 146 & 143 & 152 \\
\hline \multirow[t]{2}{*}{ Invertase } & 0 & 10.9 & 9.5 & 10.4 & 8.9 & 16.0 & 22.2 & 13.4 \\
\hline & 500 & 5.8 & 7.2 & 10.2 & 11.5 & 7.6 & 7.5 & 8.8 \\
\hline \multirow[t]{2}{*}{ Peroxidase } & 0 & 30.3 & 39.7 & 40.9 & 55.5 & 50.5 & 52.3 & 47.8 \\
\hline & 500 & 29.4 & 30.4 & 29.6 & 41.0 & 37.2 & 41.1 & 35.9 \\
\hline
\end{tabular}

${ }^{1}$ Each figure represents the computed mean of 2 replicates.

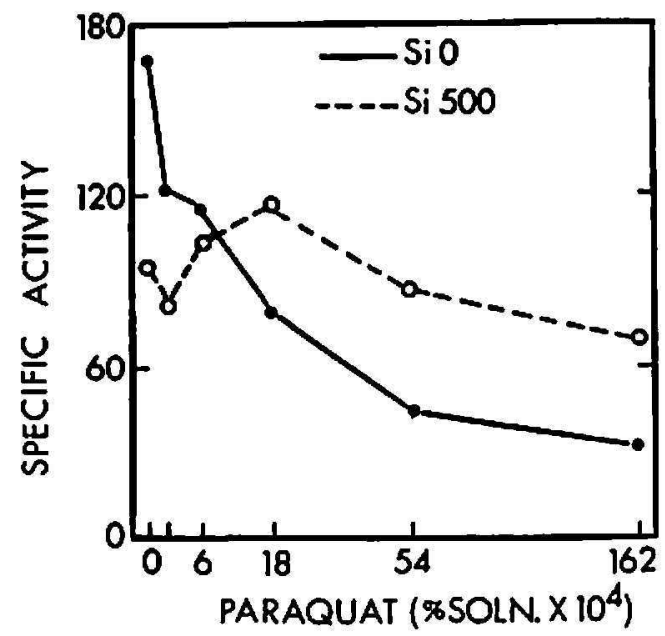

Fig. 4.-Peroxidase decline in leaves of sugarcane treated with Paraquat, and moderating effect of Si pretreatment on the enzyme's behavior.

chemicals and a logical choice for extended studies of Si-desiccant relationships. The Diquat experiment described herein verified nearly all of the results observed with Paraquat.

\section{Visual Responses to Diquat and Si}

Diquat was applied at 10:00 a.m., September 26, on a clear, hot day. Injury symptoms indistinguishable from those of Paraquat (7) and earlier 
Diquat symptoms (8) began to appear in about 5 hours. From the standpoint of chlorophyll destruction a critical range was again established between the 0.0018 and 0.0162 percent levels. Plants pretreated with $\mathrm{Si}$ again very markedly resisted foliar damage below the 0.0162 percent Diquat level.

Sheath moisture values at 5 days indicated very little desiccation-all sheaths remaining above 80 percent. This was possibly due to the plants being several weeks younger and more succulent than those treated with Paraquat. More time or a higher Diquat level may be needed to achieve desiccation effects comparable to Paraquat.
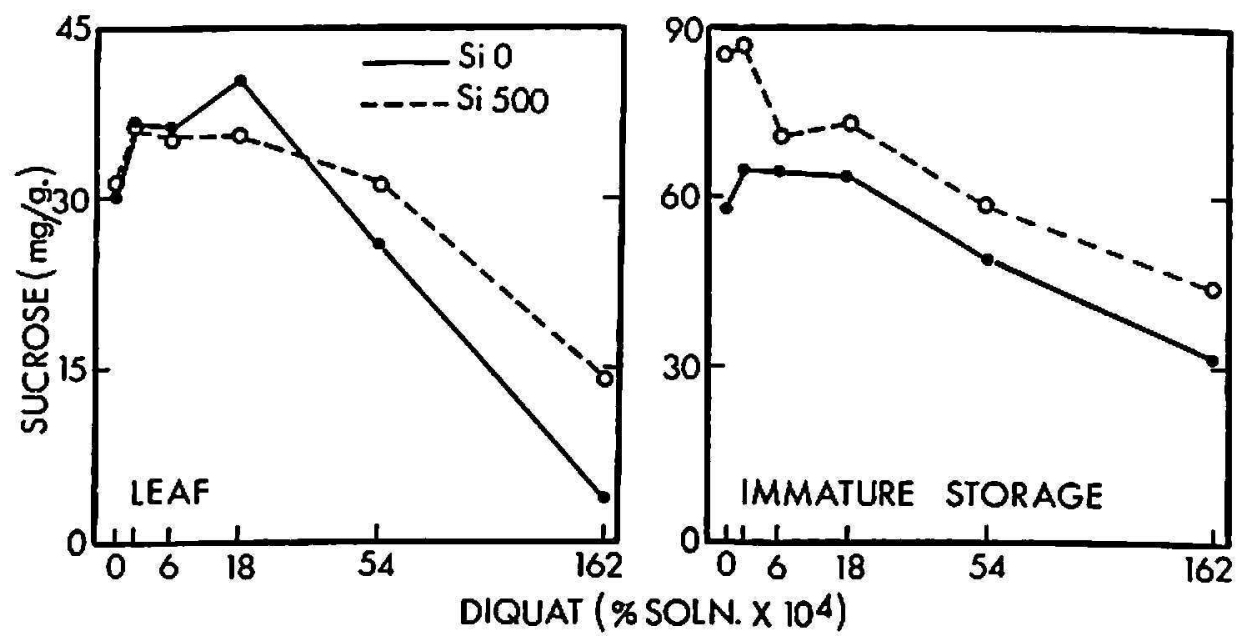

Fig. 5.-Sucrose decline in leaf and immature storage tissues of sugarcane treated with Diquat, and partial retention of sucrose in plants pretreated with foliar Si.

\section{Sugar and Enzyme Responses to Diquat and $S i$}

As was true for Paraquat, increasing Diquat levels caused sucrose losses in both leaf and immature storage tissues (fig. 5). This decline was lessened but not completely alleviated by pretreatment with $\mathrm{Si}$. Paper chromatography of leaf extracts revealed traces of ribose in plants given $0 \mathrm{Si}$ prior to Diquat (fig. 6). These are visible in the 0.0054 and 0.0162 percent treatments. Ribose did not appear in plants receiving $\mathrm{Si}$, which again supports the concept of photosynthetic "protection" by Si. Presumably a ratelimiting enzyme or enzymes, perhaps phosphoribose isomerase, was retained at a sufficient activity level by Si.

Leaf enzymes were not appreciably affected by Diquat below the 0.0054 percent level. The 0.0162 percent treatment retarded phosphatase, ATP-ase and peroxidase. In cach instance there was a modifying effect by Si similar to that recorded for Paraquat. Leaf amylase was increased by Diquat, but again to a lesser degree when leaves were pretreated with Si. 
Amylase of immature storage tissues was increased nearly 3-fold by high Diquat (table 6). Si again restricted this rise although there was some increase nonetheless. Neither invertase nor peroxidase was very greatly stimulated by Diquat, and both enzymes increased even less in plants given Si.

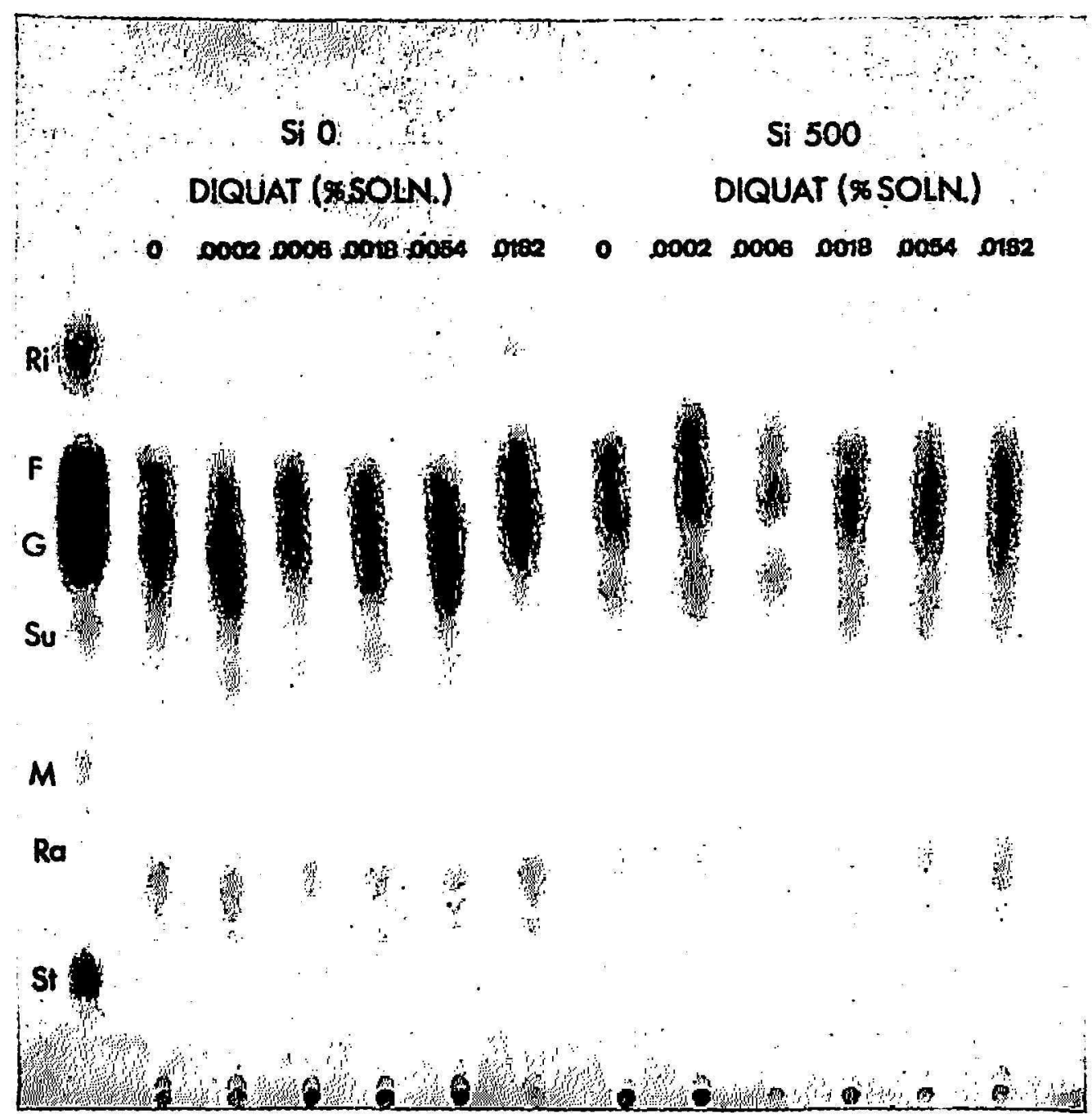

Fig. 6.-Paper chromatogram of leaf extracts from sugarcane treated with Diquat, illustrating the appearance of ribose (Ri) in response to increasing l)iquat, and delay of ribose in plants pretreated with 500 p.p.m. Si.

In retrospect Diquat did cause foliar damage, sucrose decline, and enzyme changes, but generally of lesser magnitude than Paraquat. Si alleviated these effects as it did for Paraquat, although to a somewhat lesser degree.

\section{EXPERIMENT 3: LIMITED PARAQUAT $\times$ SI}

\section{Visual Responses to Paraquat and Si}

Paraquat was employed again for the third desiccant-Si study. The objectives included verification of earlier enzyme and sugar effects, but pri- 
marily we sought to refine the techniques for chemical control. Paraquat was given only at 0 and 0.001 percent concentrations. A single Si pretreatment was given, and this only 24 hours prior to Paraquat application. No desiccation was expected; rather, we were trying to induce, and to counteract, discrete sucrose and enzyme changes believed to precede gross physical transformations.

Paraquat treatments were applied at 2:00 p.m. on a cloudy, cool Wednesday. Very slight wilting was first observed within the 0.001 percent treat-

TABLE 6.-Specific activity for enzymes of immature slorage tissue from sugarcane desiccated with foliar Diqual, and pretreated with variable $S i^{1}$

\begin{tabular}{|c|c|c|c|c|c|c|c|c|}
\hline \multirow{2}{*}{ Enzyme } & \multirow{2}{*}{$\underset{\text { (p.p.m.) }}{\mathrm{Si}}$} & \multirow{2}{*}{0} & \multicolumn{5}{|c|}{ Diquat (percent solution $\times 10^{4}$ ) } & \multirow{2}{*}{$\begin{array}{l}\text { Diquat } \\
\text { mean }\end{array}$} \\
\hline & & & 2 & 6 & 18 & 54 & 162 & \\
\hline \multirow[t]{2}{*}{ Phosphatase } & 0 & 19.1 & 17.4 & 18.9 & 23.9 & 27.9 & 26.3 & 22.9 \\
\hline & 500 & 20.6 & 20.0 & 16.1 & 21.7 & 23.1 & 22.7 & 20.7 \\
\hline \multirow[t]{2}{*}{ ATP-ase } & 0 & 24.6 & 20.9 & 26.7 & 30.8 & 36.5 & 30.2 & 29.0 \\
\hline & 500 & 20.3 & 24.4 & 22.4 & 28.8 & 29.4 & 26.9 & 26.4 \\
\hline \multirow[t]{2}{*}{ Amylase } & 0 & 56.8 & 54.9 & 85.5 & 80.0 & 123 & 152 & 99.1 \\
\hline & 500 & 42.4 & 58.8 & 50.6 & 55.7 & 65.8 & 90.8 & 64.3 \\
\hline \multirow{2}{*}{ Invertase } & 0 & 20.3 & 19.3 & 18.3 & 21.6 & 24.7 & 23.1 & 21.4 \\
\hline & 500 & 14.6 & 14.1 & 13.4 & 17.8 & 18.0 & 15.4 & 15.7 \\
\hline \multirow[t]{2}{*}{ Peroxidase } & 0 & 32.3 & 23.4 & 32.9 & 35.9 & 47.1 & 46.9 & 37.2 \\
\hline & 500 & 17.7 & 24.5 & 27.0 & 31.7 & 35.7 & 32.1 & 30.2 \\
\hline \multirow[t]{2}{*}{ Tyrosinase } & 0 & 5.9 & 5.7 & 6.3 & 7.5 & 8.3 & 8.0 & 7.2 \\
\hline & 500 & 5.9 & 6.2 & 5.8 & 6.6 & 8.4 & 6.8 & 6.8 \\
\hline
\end{tabular}

${ }^{1}$ Each figure represents the computed mean of 3 replicates.

ment on Thursday evening, but marked injury symptoms were not visible until Friday morning. Foliar wilting gradually intensified. Red to red-brown circular spots began to appear and intensified throughout the day until the foliage was largely discolored by reddish-brown blotches. Plants pretreated with Si did not exhibit foliar wilting (fig. 7). A few small, circular, reddish-brown discolorations did form but the plants' appearance remained green and essentially healthy. When leaf samples were later freeze-dried and ground, the powder retained a normal green color for Si-treated leaves; the others produced a yellowish-brown powder much like that of ovendried leaves.

The wilted condition observed for leaves was not reflected in sheath- 
moisture values. This supports earlier studies which indicated that sheathpercent moisture is not a sensitive criterion of Paraquat action (8), and that treated plants may appear to be far more desiccated than is actually the case.

\section{Sugar and Enzyme Responses to Paraquat and Si}

Leaf sucrose values summarized in table 7 reveal major losses occurring between 0 and 5 days as a result of Paraquat action. It is significant that
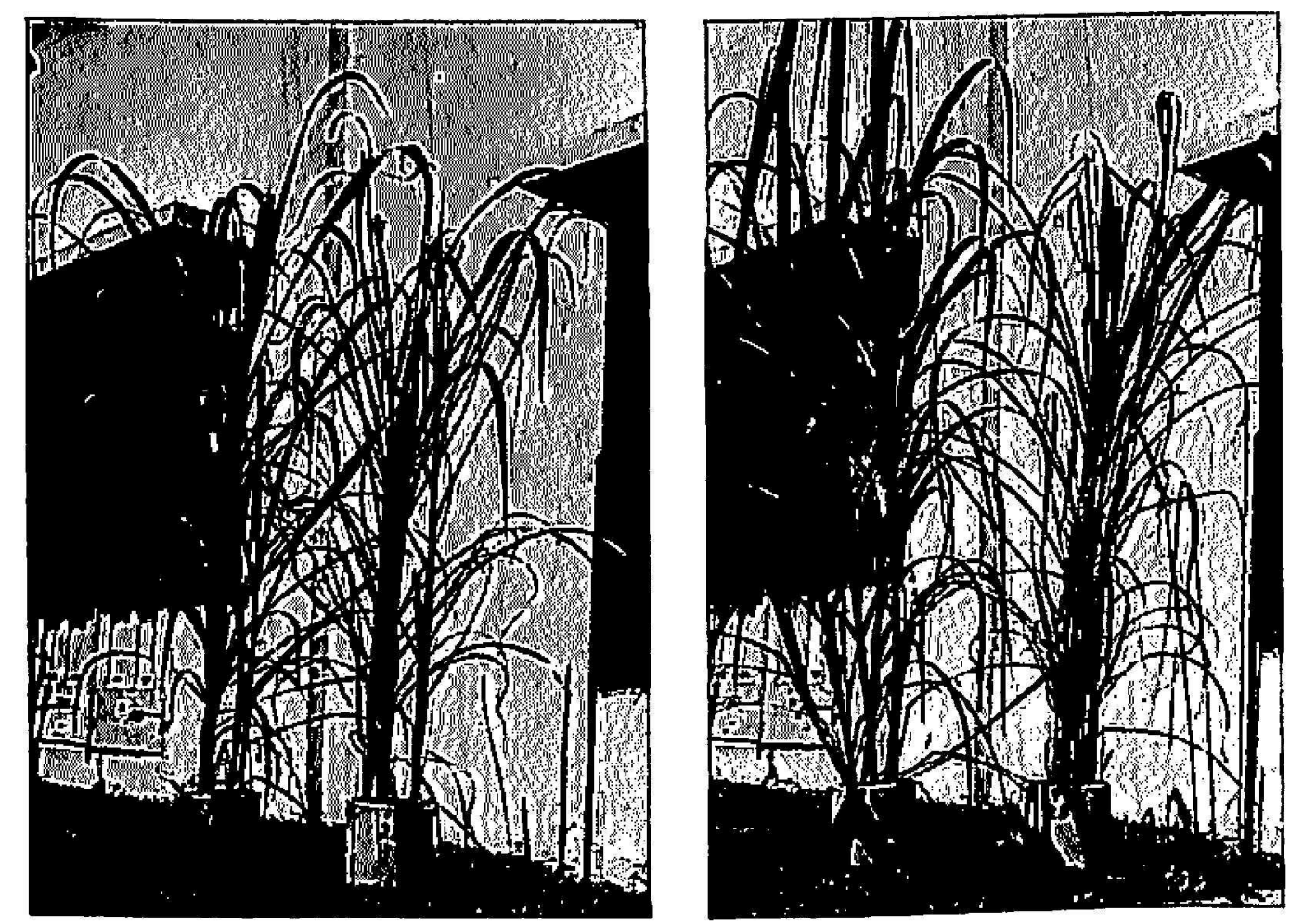

Fig. 7-Two replicates from experiment 3 illustrating the visual effects of Paraquat and Si on cane foliage. All plants received a single foliar application of 0.001 percent Paraquat 5 days before the photographs were taken. In both photographs, the left-hand container of plants had been pretreated with a single Si application (500 p.p.m.) 24 hours prior to Paraquat.

0 Paraquat plants increased sucrose during this period. These Paraquatinduced losses were largely countered by the single $\mathrm{Si}$ foliar treatment (table 7). Sucrose declined moderately in immature storage tissue, in response to 0.001 percent Paraquat, but again this effect was prevented by $\mathrm{Si}$.

There were no major differences in leaf enzyme behavior among any of the treatments. This suggests that photosynthesis decline and its prevention by $\mathrm{Si}$ accounted for the variations in leaf sucrose. In immature storage tissue, amylase and invertase behaved much as they did in experiment 1 (table 8). Both enzymes generally increased among 0 Paraquat treatments between harvests. Paraquat, without Si, greatly advanced these trends. 
Si again restricted the added amylase activity while invertase was thoroughly held in check by Si.

Experiment 3 generally verifies the earlier findings with Paraquat even though treatments were intentionally much less severe.

TABLE 7.-Leaf sucrose content of sugarcane sprayed with Paraquat and pretreated with variable Si1

\begin{tabular}{l|c|c|c|c|c|c|c}
\hline & \multirow{5}{*}{ Data classification } & \multicolumn{5}{|c}{ Paraquat (percent solution) } \\
\cline { 2 - 7 } & Harvest (days) & \multicolumn{3}{|c|}{0} & \multicolumn{2}{|c}{0.001} \\
\cline { 2 - 7 } & & Sio & Siroo & Mean & Sio & Sisoo & Mean \\
\hline Sucrose (mg./ & 0 & 58.6 & 58.7 & 58.7 & 61.3 & 55.0 & 58.2 \\
g.) & 5 & 78.2 & 82.1 & 80.0 & 26.9 & 56.5 & 41.7 \\
\hline & Mean & 68.4 & 70.4 & & 44.1 & 55.8 & \\
\hline
\end{tabular}

${ }^{1}$ Each figure represents the computed mean of 3 replicates.

TABLE 8.-Specific activity values for amylase and invertase of immature slorage tissue from sugarcane sprayed with Paraquat and pretreated with variable SiI

\begin{tabular}{|c|c|c|c|c|c|c|c|}
\hline \multirow{3}{*}{ Enzyme } & \multirow{3}{*}{ Harvest (days) } & \multicolumn{6}{|c|}{ Paraquat (percent solution)- } \\
\hline & & \multicolumn{3}{|c|}{0} & \multicolumn{3}{|c|}{0.001} \\
\hline & & Sio & Sireo & Mean & Sio & Sisueo & Mean \\
\hline Amylase & $\begin{array}{l}0 \\
5\end{array}$ & $\begin{array}{l}35.9 \\
45.3\end{array}$ & $\begin{array}{l}49.6 \\
61.3\end{array}$ & $\begin{array}{l}42.8 \\
53.3\end{array}$ & $\begin{array}{l}41.3 \\
72.7\end{array}$ & $\begin{array}{l}37.1 \\
55.1\end{array}$ & $\begin{array}{l}39.2 \\
21.9\end{array}$ \\
\hline Invertase & $\begin{array}{l}0 \\
5\end{array}$ & $\begin{array}{l}6.4 \\
9.2\end{array}$ & $\begin{array}{l}7.3 \\
9.0\end{array}$ & $\begin{array}{l}6.9 \\
9.1\end{array}$ & $\begin{array}{r}6.6 \\
12.1\end{array}$ & $\begin{array}{l}6.3 \\
5.8\end{array}$ & $\begin{array}{l}6.4 \\
8.9\end{array}$ \\
\hline
\end{tabular}

1 Each figure represents the computed mean of 3 replicates.

\section{SIGNIFICANCE OF DESICCANT CONTROL}

Taken as a group, the three experiments achieved nearly all of their objectives. They produced data clearly supporting the thesis that chemical effects on sugarcane can be modified selectively and with precision. To carry this concept a bit further, it may be possible to increase the scope and productivity of a given chemical. It is not unlikely that numerous new compounds are being screened, at no small expense, while older ones are set aside before their action is understood, and consequently, before their ultimate potential is approached. 


\section{SUMMARY}

Sugarcane studies have shown that the desiccants Paraquat and Diquat cause severe sucrose losses as a result of interrupted photosynthesis and abnormal behavior of sugar-metabolizing enzymes. It was theorized that an appropriate agent, selective for the sucrose-limiting enzymes, could modify the sugar-destroying features of otherwise useful chemicals. Experiments are reported herein in which silicon (Si), an in vitro inhibitor of cane enzymes, was applied to sugarcane foliage prior to treatment with Paraquat and Diquat. There were three objectives: 1 , To incorporate sufficient $\mathrm{Si}$ into living tissues to control hydrolytic and oxidative enzymes; 2 , to help retain photosynthetic activity; and 3, to maintain higher sucrose levels as a consequence of lessened sugar metabolism and continued photosynthesis.

Plants of the variety P.R. 980 were grown in sand culture and treated with the following percent solutions of Paraquat and Diquat: 0, 0.0002, 0.0006, 0.0018, 0.0054, and 0.0162. For each experiment half of the plants were pretreated with 500 p.p.m. of $\mathrm{Si}\left(\mathrm{Na}_{2} \mathrm{SiO}_{3} \cdot 9 \mathrm{H}_{2} \mathrm{O}\right)$ as a foliar spray at 8,4 , and 1 day prior to desiccant application. The following results were obtained:

1. The 0.0018 to 0.0162 percent levels severely damaged cane foliage, desiccated leaves and sheaths, and caused major sucrose losses in plants not pretreated with $\mathrm{Si}$.

2. Si-pretreated plants retained near-normal foliage and near-normal sucrose levels for approximately two Paraquat increments above those of non-pretreated plants. For example, damage typical of the 0.0018 percent level, without $\mathrm{Si}$, did not appear until the $\mathbf{0 . 0 1 6 2}$ percent level was reached when $\mathrm{Si}$ was present.

3. Paraquat desiccation, as reflected by sheath-moisture values, was ultimately constant regardless of Si treatment.

4. Paper chromatography revealed ribose in leaf extracts of Paraquatand Diquat-treated plants. Si pretreatment retarded the appearance of ribose below the $\mathbf{0 . 0 1 6 2}$ percent level of Paraquat, and at all Diquat levels. This indicated a Si "protection" of photosynthetic reactions, possibly those of phosphoribose isomerase.

5. The leaf enzymes phosphatase, ATP-ase, and peroxidase were suppressed by increasing desiccant concentrations. Si pretreatments acted to preserve near normal enzyme levels regardless of desiccant action. Leaf amylase, and invertase from immature storage tissue, were greatly stimulated by Paraquat. In these instances $\mathrm{Si}$ served to suppress the excessive enzyme activity.

6. Si did not seem to act as an inhibitor in living tissues, as it is known to do in the test tube. Rather, a series of Si-enzyme complexes appeared to form and to retard activity shifts in either direction. 
7. A third experiment involving 0.001 percent Paraquat, and a single Si pretreatment given 1 day prior to Paraquat, generally verified the sucrose, enzyme, and visible foliar effects noted earlier with more severe desiccant and $\mathrm{Si}$ treatments.

The results support the thesis that undesirable effects of a chemical on plants can be selectively modified by control of critical enzymes. The value of this concept in increasing the scope and productivity of agricultural chemicals is noted.

\section{RESUMEN}

Los estudios con la caña de azúcar han demostrado que los desecantes Paraquat y Diquat causan graves pérdidas de sacarosa como resultado de una fotosintesis interrumpida y un comportamiento anormal de las enzimas metabolizadoras del azúcar. Se teorizb sobre que un agente apropiado, selectivo para las enzimas limitativas de la sacarosa, podría modificar las propiedades que poseen ciertos compuestos químicos útiles en otros respectos, para destruir el azúcar. Se informan aquí experimentos en los que el silicio (Si), inhibidor in vitro de las enzimas de la caña, se aplicó al follaje de la planta con anterioridad al tratamiento con Paraquat y Diquat. Fueron tres los objetivos: 1, Incorporar suficiente silicio al tejido vivo para controlar las enzimas hidroliticas y oxidantes; 2, ayudar a retener la actividad fotosintética; y 3, mantener altos niveles de sacarosa como consecuencia de un menguado metabolismo del azúcar y una fotosintesis prolongada.

Plantas de la variedad P. R. 980 se cultivaron en arena y se trataron con soluciones de Paraquat y Diquat al 0, 0.0002, 0.0006, 0.0018, 0.0054 y 0.0162 por ciento. En cada experimento la mitad de las plantas se trataron con 500 p.p.m. de $\mathrm{Si}\left(\mathrm{Na}_{2} \mathrm{SiO}_{3} \cdot 9 \mathrm{H}_{2} \mathrm{O}\right)$ en forma de aspersión foliar 8 días, 4 y 1 antes de la aplicación del desecante. Se obtuvieron los siguientes resultados:

1. Los niveles de 0.0018 a 0.0162 por ciento fueron marcadamente nocivos al follaje de la caña de azúcar, desecaron las hojas y yaguas y causaron pérdidas mayores de sacarosa en las plantas no tratadas con Si.

2. Las plantas pretratadas con Si conservaron un follaje casi normal y niveles de sacarosa cercanos al normal en aproximadamente dos incrementos de Paraquat más elevados que los de las plantas no pretratadas. Por ejemplo, el daño típico al nivel de 0.0018 por ciento, sin silicio, no apareció hasta no alcanzarse el nivel de 0.0162 por ciento en presencia de Si.

3. La desecación con Paraquat, reflejada en los valores de humedad de las yaguas, fue esencialmente constante, sin importar el tratamiento son $\mathrm{Si}$.

4. La cromatografía sobre papel reveló la presencia de ribosa en los extractos foliares de las plantas tratadas con Paraquat y Diquat. El pretratamiento con Si retardó la aparición de ribosa a un nivel inferior al 
0.0162 por ciento de Paraquat, y en todos los niveles de Diquat. Esto indica que el Si "protege" a las reacciones fotosintéticas, posiblemente las de la isomerasa de fosforribosa.

5. Las enzimas foliares tales como la fosfatasa, la ATP-asa y la peroxidasa fueron reprimidas mediante un aumento en la concentración del desecante. Los pretratamientos de Si mantuvieron cerca de la normalidad los niveles enzimáticos, a pesar de la acción del desecante. La amilasa foliar y la invertasa del tejido reservante tierno fueron grandemente estimuladas por el Paraquat. En estos casos el Si sirvió para reprimir la excesiva actividad enzimática.

6. Parece que el Si no actuó como inhibidor en el tejido vivo, tal como ocurre in vitro. Al contrario, tal parece que se formaron una serie de complejos Si-enzima, los cuales retardaron los cambios de actividad en una y otra dirección.

7. Un tercer experimento que incluía 0.001 por ciento de Paraquat y un pretratamiento único de Si dado 1 día antes del tratamiento con Paraquat, verificó, en general, los efectos en la sacarosa, en las enzimas y los efectos visibles en el follaje, que se observaron antes con tratamientos más severos del desecante y Si.

Los resultados confirman la tesis de que los efectos indeseables de un compuesto químico pueden ser selectivamente modificados mediante la regulación de las enzimas críticas. Se señala el valor que puede tener este concepto al aumentar el alcance y la utilidad de los productos químicos en la agricultura.

\section{LITERATURE CITED}

1. Alexander, A. G., Sucrose-enzyme relationships in immature sugarcane as affected by variable nitrate and potassium supplied in sand culture, J. Agr. Univ. P.R. 48 (3): 165-231, 1964.

2. - Hydrolytic proteins of sugarcane: The acid phosphatases, J. Agr. Univ. P.R. 49 (2): 204-28, 1965.

3. - Hydrolytic proteins of sugarcane: The acid invertases, J. Agr. Univ. P.R. 49 (3): 207-307, 1965.

4. - Hydrolytic proteins of sugarcane: Amylase, J. Agr. Univ. P.R. 49 (3): 308-24, 1965.

5. - - Oxidizing enzymes of sugarcane: Peroxidase, J. Agr. Univ. P.R. 50 (1): 36-52, 1966.

6. - , Oxidizing enzymes of sugarcane: Tyrosinase, J. Agr. Univ. P.R. 50 (2): 113-30, 1966.

7. - , and Montalvo-Zapata, R., Enzyme studies of sucrose decline in sugarcane desiccated with Paraquat, J. Agr. Univ. P.R. 65 (4): 230-50, 1969.

8. - , and - Enzymatic factors in the sucrose decline of sugarcane desiceated with Paraquat, Diquat, and Dinitro-butyl-phenol, J. Agr. Univ. P.R. 54 (1): 28$49,1970$.

9. Alexander, A. G., Preservation of sucrose in sugarcane juice with sodium meta- 
silicate, Informe Técnico no. 26, Agricultural Experiment Station of the University of Puerto Rico, Mayagüez Campus, Río Piedras, P.R., 1968.

10. In vitro effects of silicon on hydrolytic and oxidative enzymes of sugarcane, 19th Cong. Intnl. Soc. Sugarcane Technol. Preprint no. A-03, 1968.

11. Cardini, C. E., Leloir, L. F., and Chiriboga, J., The biosynthesis of sucrose, $J$. Biol. Chem. 214: 149-55, 1955.

12. Dube, S. K., and Nordin, P., Isolation and properties of sorghum alpha-amylase, Arch. Biochem. and Biophys. 94: 121-7, 1961.

13. Roe, J. R., A colorimetric method for the determination of fructose in blood and urine, J. Biol. Chem. 10\%: 15-22, 1934.

14. Sumner, James B., Dinitrosalicylic acid: A reagent for the estimation of sugar in normal and diabetic urine, J. Biol. Chem. 47: 5-9, 1921.

15. Sutherland, E. W., Cori, C. F., Haynes, R., and Olsen, N. S., Purification of the hyperglycemic-glycogenolytic factor from insulin and from gastric mucosa, J. Biol. Chem. 180: 825-37, 1949. 